Plant Tissue Cult. \& Biotech. 23(2): 165-176, 2013 (December)

\title{
In vitro Mass Propagation of Artemisia (Artemisia annua L.) cv: Anamed
}

\section{Tilahun Hailu, Balcha Abera* and Elias Gabra Mariam ${ }^{1}$}

Department of Biology, Jimma University, Ethiopia

Key words: Artemisinin, Mass propagation, Microshoots, Microcuttings

\begin{abstract}
An efficient in vitro propagation protocol was developed for anamed (A-3) cultivar of Artemisia annua. Two and $1.5 \%$ concentration of $\mathrm{NaOCl}$ treatment for 10 and 20 min were found to be optimum for sterilization of shoot tip and nodal explants, respectively. Maximum percentage $(98.75 \pm 2.50)$ shoot induction was observed from nodal explants cultured on MS supplemented with $0.8 \mathrm{mg} / \mathrm{BAP}+$ $0.1 \mathrm{mg} / \mathrm{l} \mathrm{IBA}$ followed by $82.50 \pm 2.88 \%$ from shoot tip explants on the same medium with $0.8 \mathrm{mg} / \mathrm{lDZ}$ for shoot tip explants. The highest number of shoots (8.05 \pm 0.66/explant) was regenerated on MS $+1 \mathrm{mg} / \mathrm{l} \mathrm{BAP}+0.1 \mathrm{mg} / \mathrm{l} \mathrm{IBA}$. Best rooting with mean values of $18.25 \pm 0.95 /$ explant root number and root length $(6.35 \pm 0.10 \mathrm{~cm})$ was recorded on $1 / 2 \mathrm{MS}+0.5 \mathrm{mg} / \mathrm{l} \mathrm{IBA}$. Up on acclimation and transplanting, $80 \%$ survival efficiency was observed on the soil mix ratio of $2: 1: 1$ (decomposed coffee husk, forest soil and sand, respectively). The developed regeneration protocol enables a large scale commercial production and a possible system towards the genetic improvement of this crop.
\end{abstract}

\section{Introduction}

Artemisia (Artemisia annua L.) is a medicinal herb (Asteraceae). It is a crop for the production of artemisinin, a sesquiterpene lactone with anti-malarial effects against susceptible and multi-drug resistant Plasmodium species, originated in China (Tiruneh et al. 2010). Now, A. annua grows throughout the temperate regions of the world (Ferreira et al. 2005). In Africa, Artemisia is currently cultivated in Cameron, Ethiopia, Kenya, Mozambique, Tanzania, Uganda and Zambia - all in high-altitude regions and/or regions with a pronounced cool period (Ferreira and Janick 2002, EABL 2005).

*Author for correspondence: <balcha_abea@yahoo.com>. 1Jimma Agricultural Research Institute, Ministry of Agriculture, Ethiopia. 
Artemisia species are one of the many traditional medicinal plants used for the treatment of infectious and non-infectious health problems. A. annua L. is one of the plant species listed the WHO monographs. The selection of medicinal plants for inclusion in the WHO monographs is based on their worldwide use (WHO 2003). At present, Artemisia is processed by pharmaceutical firms for the production of artemisin for Artemisin based combination therapies (ACTs) in the treatment of malaria (Ferreira and Janick 1995, WAC 2007). Three native Artemisia species (A. absinthium, A. abyssinica, and A. afra) are found in Ethiopia which was validated for the treatment of protozoal infections (Nibret and Wink 2010). A. апnиa was introduced to Ethiopia in 2001 in the form of traditional tea to cure malaria, asthma, hemorrhoid etc. The conventional propagation of Artemisia by seeds is a constraint for its production due to its tiny seeds that require a symbiotic association within its own microflora for germination. Micropropagation enables rapid rate of clonal multiplication of an elite plant species, allowing production of disease-free, genetically stable and uniform progenies (Hu and Wang 1983). Micropropagation of different Artemisia species such as $A$. scorpia has been previously established and reported by various authors (Aslam et al. 2006), A. vulgaris (Sujata and Kumari 2007, Govindaraj et al. 2008). There are a few reports on micropropagation of $A$. annua cultivars other than anamed using shoot explants. Most reports suggest a strong influence of genotype on the proliferation process (Elhag et al. 2006). Almaarri and Yu Xie (2010). To develop an efficient protocol that enables rapid in vitro multiplication of A. annua anamed (A-3) from shoot tip and nodal explants.

\section{Materials and Methods}

Healthy and vigorously growing young plants of A. annua A-3 cultivar raised from stem cuttings were obtained from Wondo-Genet Agricultural Research Center (WARC), then transplanted in pots, grown in the lath-house, and used as a source of explants (Fig. 1). Shoot tip explants (1 - $1.5 \mathrm{~cm}$ long) and nodal explants (1.5 - $2 \mathrm{~cm}$ long) from middle lateral branches were excised and washed three times with tap water and commercial liquid detergent using a piece of sponge. The cleaned explants were then transferred to the laminar flow hood, immersed in $70 \%(\mathrm{v} / \mathrm{v})$ ethanol for $30 \mathrm{sec}$, rinsed in sterile distilled water three times and surface sterilized further using $\mathrm{NaOCl}$ disinfectant solutions for the specified time, as per the treatment combinations. Finally, the explants were rinsed four times with double distilled water.

The sterilized shoot tip and nodal explants were further cut down to 5 to 15

$\mathrm{mm}$ size by trimming all the dead and chlorine affected tissues prior to culture. They were then cultured in a plant growth regulator free medium of half 
strength MS supplemented with $15 \mathrm{~g} / \mathrm{l}$ sucrose, and solidified with $7 \mathrm{~g} / \mathrm{l}$ agaragar for 72 hrs. Explants that have shown early contamination and tissue death in the media were recorded and discarded.

For culture initiation, agar solidified (0.7\% agar-agar) full strength MS added with 3\% sucrose was supplemented with different concentrations of BAP and TDZ. The experiments were carried out with a treatment combination of four different concentrations of $\operatorname{BAP}(0,0.4,0.8$, and $1.2 \mathrm{mg} / \mathrm{l})$ and four different concentrations of $\operatorname{TDZ}(0,0.4,0.8$, and $1.2 \mathrm{mg} / \mathrm{l})$ alone and in combination at each concentration with $0.1 \mathrm{mg} / \mathrm{l} \mathrm{IBA}$. Experiments were carried out using CRD design in $4 \times 4 \times 2 \times 2$ factorial combinations.

Responsive shoot buds were transferred singly in a shoot multiplication medium. The shoot multiplication media used were composed of MS fortified with $30 \mathrm{~g} / \mathrm{l}$ sucrose and different concentrations of $\operatorname{BAP}(0,0.25,0.5,0.75,1.0,1.25$ and $1.5 \mathrm{mg} / \mathrm{l}$ ) each alone and interacting at each concentration with $0.5 \mathrm{mg} / \mathrm{l} \mathrm{Kn}$ or $0.1 \mathrm{mg} / \mathrm{l} \mathrm{IBA}$. After three-four weeks, cultures proliferating shoot clumps were divided and subcultured on to a fresh medium.

Well developed microcuttings were transferred for rooting. For shoot elongation and rooting on agar solidified $(0.7 \%$ agar-agar) half and full strength MS added with 3\% sucrose was supplemented with different concentrations of IBA and NAA. Elongated plantlets (shoots with well-developed roots) were taken for acclimation. Individual $A$. annua plantlets were removed from the flasks and washed carefully under warm water to facilitate the removal of adhering agar from the root surface, rinsed in a fungicidal solution of $3 \%$ Kocide101, and transferred to a sterilized potting mix of forest soil : sand : well decomposed coffee husk at a ratio (v/v) of $1: 1: 2$ and kept under a plastic tunnel of high humidity $(80-90 \%)$ to prevent desiccation for ten days. After the tenth day, plantlets were transferred to a $70 \%$ shade net, where they were kept for another month. Later, they were transferred to a $30 \%$ shade net where they were maintained for another month, prior to field transplanting.

The average of the data collected from two repetitions for each experiment were independently subjected to statistical analysis using the SAS statistical software (version 9.2) and ANOVA was constructed, followed by mean separation using appropriate procedures (REGWQ). When ANOVA indicated significant treatment effects $(5,1$ or $0.1 \%)$ based on the F-test, probability level of 0.05 ( $p \leq 0.05)$ was considered to determine which treatments were statistically different from the remainder. 


\section{Results and Discussion}

The effect of different concentrations of sodium hypochlorite solutions and different time durations of explants exposure to the sterilants were evaluated for determining the most effective treatment combination on sterilization of shoot tip and nodal explants. The analysis of variance showed that the concentration of sodium hypochlorite solution, time duration of explants exposure to the sterilants and interaction of concentrations to time duration had highly significant effect $(\mathrm{p}<0.0001)$ on both of contamination and tissue death of shoot tips and nodal explants. The highly significant difference was also revealed between the two types of explants (treatment: explants $=p<0.0001$ ) indicating that the level of contamination and tissue death was influenced by explants type and the mean average value for contamination and tissue death of shoot tips exceeded that of node explants.

The highest rate of contaminant free culture $(48.33 \pm 1.34)$ was obtained from treatment combinations of 1.5 and $2 \%$ concentration of $\mathrm{NaOCl}$ and 20 and $25 \mathrm{~min}$ exposure duration respectively for shoot tip explants. For nodal explants $1.5 \%$ concentration and 20 min exposure duration were found to be the most effective treatment combination with mean average result of $81.66 \pm 1.34 \%$ contaminant free lively cultures (Table 1).

Increasing the sterilant concentration from 0.5 to $2 \%$ active chlorine maintaining $10 \mathrm{~min}$ exposure duration constant had reduced the rate of contamination from $86.66 \pm 2.88 \%$ to zero and from $78.33 \pm 2.88 \%$ to zero for shoot tips and nodal explants, respectively. However, only $48.33 \pm 1.34 \%$ for shoot tips and $68.33 \pm 2.88 \%$ for nodal explants survived to grow and develop. This effect was mainly attributed to the high level of tissue death i.e., $51.66 \pm$ $2.88 \%$ for shoot tips and $31.66 \pm 2.88 \%$ for nodal explants caused by the maximum concentration of the sterilant solution. Exposure duration of explants to the sterilant chemical also had significantly affected the effectiveness of the chemical in that it increased in time from 10 to $25 \mathrm{~min}$ at two per cent constant concentration had decreased the percentage of clean lively culture from $48.33 \pm$ 1.34 to $36.66 \pm 0.13$ and from $68.33 \pm 2.88$ to $40.00 \pm 0.00$ for shoot tip and nodal culture, respectively increasing the rate of tissue death (Table 1). The rate of tissue death severely affected shoot tip explants than nodal explants as shoot tip tissues are relatively young and more susceptible to the chemical action.

Generally, occurrence of high contamination rate of culture at a relatively lower concentration and shorter exposure time treatment combinations was possibly due to the insufficiency of sterilant concentration and exposure duration to remove or kill the contaminant agents mainly fungi and bacteria. High 


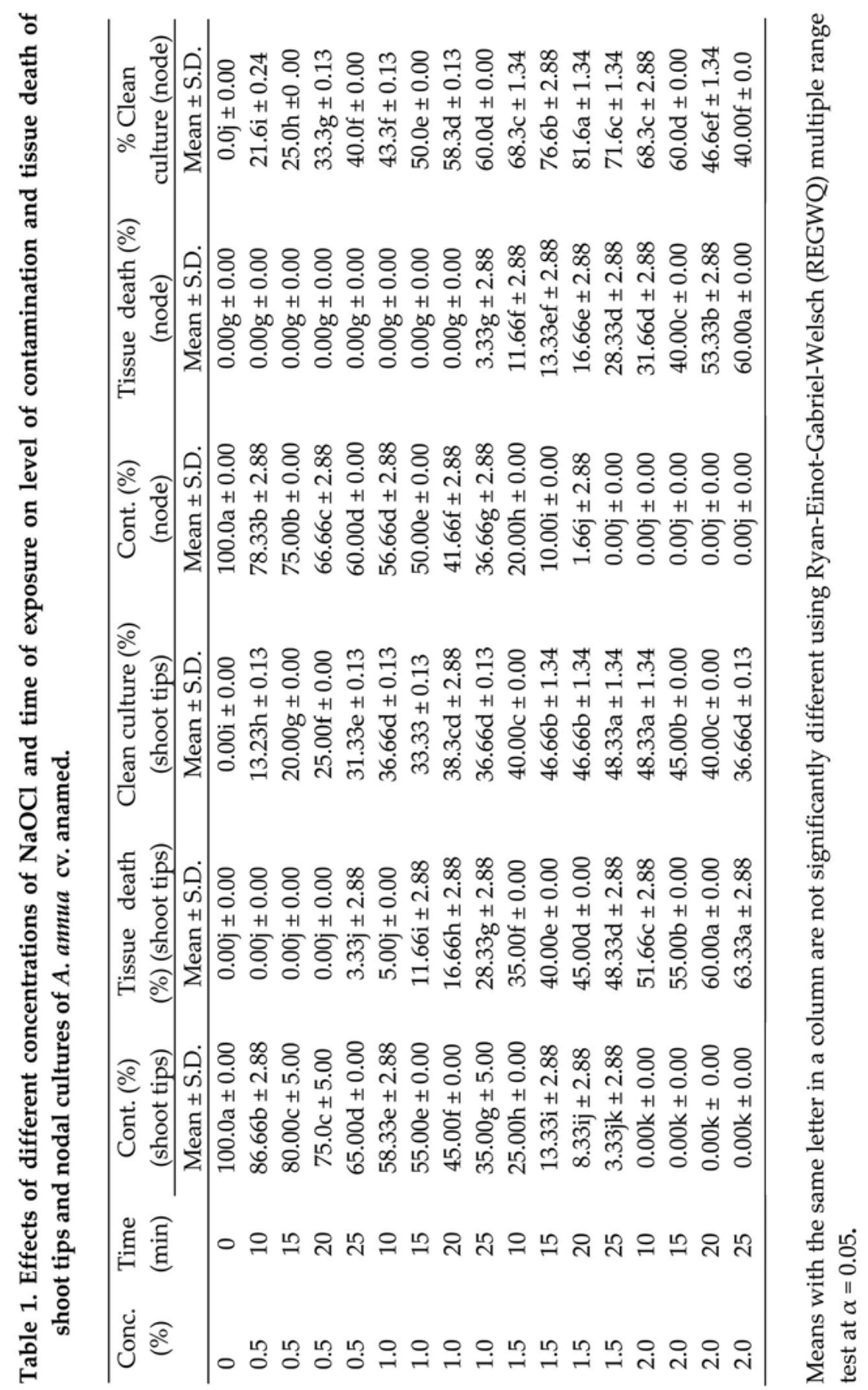


concentration of $\mathrm{NaOCl}$ and long exposure duration of explants in the sterilant solution resulted better removal of microbes due to the powerful oxidant property of active chlorine that disintegrates the lipids in the cell wall of bacteria and fungi. The effect of the sterilant chemical could also alter or denature the shape and function of microbial enzymes (George et al. 2008). However, the increase in sterilant concentration and exposure time above certain optimum limit cause loss of explants because of the oxidant chemical ingredient killing the plant tissue as well. Hence, the optimum treatment combination (concentration and time) for effective sterilization of explants should be determined based on the two aspects of the observations, i.e. a relatively minimum level of contamination as well as tissue death that gives the maximum percentage of clean lively culture as indicated in Table 1 .

The present result is partially in agreement with Nair et al. (1986) who reported the minimum level of contamination with $1.5 \%$ active chlorine in $\mathrm{NaOCl}$ solution for $15 \mathrm{~min}$. Almaarri and Yu Xie (2010) similarly reported 1\% chlorox (a commercial preparation of $\mathrm{NaOCl}$ with $5.25 \%$ active chlorine) for 15 min as effective treatment combination for sterilization of shoot tip leaf and nodal explants. Sujata and Kumari (2007) reported the use of $0.1 \%$ mercuric cloride for $3 \mathrm{~min}$ as effective treatment to remove microbes from shoot tip and nodal explants on initiation of aseptic culture in vitro. The use of mercuric chloride however, is highly discouraged as such chemicals have been known to have a serious harmful residual effect to both human and the environment. Thus, the trend is to try for the substitute with a relatively safe or less harmful chemical such as $\mathrm{NaOCl}$ solution as employed in this study.

The nodal explants gave greater response than shoot tip explants (Table 2). Although it requires further investigation to be carried out, this might be related to the variation in endogenous level of auxin in shoot tip- and nodal sections of the given genotype (Hopkins and Huner 2004).

The highest rate of shoot induction $(98.75 \pm 2.50 \%)$ was obtained on MS medium supplemented with $0.8 \mathrm{mg} / \mathrm{l} \mathrm{BAP}$ and $0.1 \mathrm{mg} / \mathrm{l} \mathrm{IBA}$ from nodal explants while shoot tip ( $82.50 \pm 2.88 \%$ ) on MS containing $0.8 \mathrm{mg} / \mathrm{l} \mathrm{TDZ} \mathrm{(Table} \mathrm{2).} \mathrm{For} \mathrm{both}$ shoot tip and nodal explants, MS supplemented with $0.8 \mathrm{mg} / \mathrm{l} \mathrm{BAP}$ or $0.8 \mathrm{mg} / \mathrm{l}$ TDZ used alone or in combination with $0.1 \mathrm{mg} / \mathrm{l} \mathrm{IBA}$ were found to be the optimum media for in vitro shoot initiation of A. annua (Table 2). From all treatments the minimum rate of shoot induction was observed on MS containing $0.4 \mathrm{mg} / \mathrm{l} \mathrm{TDZ}$ and $0.1 \mathrm{mg} / \mathrm{l} \mathrm{IBA}(1.25 \pm 2.50 \%$ and $6.25 \pm 4.78 \%)$ for shoot tip- and nodal explants, respectively.

Shoot bud development capacity of both shoot tip- and nodal cultures increased with the increase in concentration of BAP and TDZ from zero to 0.8 
$\mathrm{mg} / \mathrm{l}$ and reduced with further addition of both BAP and TDZ. This could be due to the exogenous application of cytokinins which release shoot buds from apical dominance. The addition of optimum amount, however, might reduce shoot induction rate by inhibiting the availability of the required endogenous amount of auxin for shoot initiation as cytokinins do not act alone unless combined with auxins.

Table 2 Effects of BAP, TDZ and IBA on in vitro shoot induction rate of A. annua from shoot tip and nodal explants culture on MS.

\begin{tabular}{cccccc}
\hline \multicolumn{3}{c}{ Plant growth regulators } & & \multicolumn{2}{c}{ Shoot bud induction $(\%)$} \\
\cline { 1 - 2 } \cline { 5 - 6 } BAP $(\mathrm{mg} / \mathrm{l})$ & TDZ $(\mathrm{mg} / \mathrm{l})$ & IBA $(\mathrm{mg} / \mathrm{l})$ & & Shoot tip & Node \\
\hline 0 & 0 & 0 & & $6.25 \mathrm{~h} \pm 4.78$ & $0.00 \mathrm{i} \pm 0.00$ \\
0.4 & 0 & 0 & & $42.50 \mathrm{~cd} \pm 2.88$ & $53.75 \mathrm{c} \pm 2.5$ \\
0.8 & 0 & 0 & & $81.25 \mathrm{a} \pm 2.50$ & $93.75 \mathrm{a} \pm 4.78$ \\
1.2 & 0 & 0 & & $30.00 \mathrm{e} \pm 0.00$ & $36.25 \mathrm{e} \pm 2.50$ \\
0 & 0.4 & 0 & & $40.00 \mathrm{~d} \pm 0.00$ & $51.25 \mathrm{c} \pm 2.50$ \\
0 & 0.8 & 0 & & $82.50 \mathrm{a} \pm 2.88$ & $88.75 \mathrm{a} \pm 2.50$ \\
0 & 1.2 & 0 & & $26.25 \mathrm{f} \pm 2.50$ & $31.25 \mathrm{f} \pm 2.50$ \\
0.4 & 0 & 0.1 & & $22.50 \mathrm{~g} \pm 2.88$ & $25.00 \mathrm{~g} \pm 0.00$ \\
0.8 & 0 & 0.1 & & $78.75 \mathrm{~b} \pm 2.50$ & $98.75 \mathrm{a} \pm 2.50$ \\
1.2 & 0 & 0.1 & & $46.25 \mathrm{c} \pm 2.50$ & $50.00 \mathrm{c} \pm 2.50$ \\
0 & 0.4 & 0.1 & & $1.25 \mathrm{i} \pm 2.50$ & $6.25 \mathrm{~h} \pm 4.78$ \\
0 & 0.8 & 0.1 & & $67.50 \mathrm{bc} \pm 2.88$ & $85.00 \mathrm{a} \pm 0.00$ \\
0 & 1.2 & 0.1 & & $40.00 \mathrm{~d} \pm 0.00$ & $46.25 \mathrm{~d} \pm 2.50$ \\
\hline
\end{tabular}

Means with the same letter in a column are not significantly different as determined by Ryan-Einot-Gabriel-Welsch (REGWQ) multiple range test at $\alpha=0.05$.

A low concentration of auxin together with a relatively high concentration of cytokinin is reported to be useful for shoot induction; although it has been repeatedly reported that exogenous auxin does not promote axillary shoot proliferation (George et al. 2008). Such an effect was observed in the present study that, the combination of BAP and IBA produced the best response when the low concentration of auxin $(0.1 \mathrm{mg} / \mathrm{l} \mathrm{IBA})$ is combined with a relatively higher concentration of cytokinins (Table 2). The combination of $0.4 \mathrm{mg} / \mathrm{l} \mathrm{BAP}$ and $0.1 \mathrm{mg} / \mathrm{l} \mathrm{IBA}$ gave no or very low response of shoot bud induction rather than callus formation while the same amount of IBA with $0.8 \mathrm{mg} / \mathrm{l}$ BAP produced the highest shoot induction and even with the maximum $1.2 \mathrm{mg} / \mathrm{l} \mathrm{BAP}$ better results were obtained (Table 2). This backs up the knowledge that, it is the ratio of auxin to cytoknin, not the absolute level of auxin that suppresses shoot bud growth (Hartmann et al. 2009). 
The present result of shoot induction rate is in agreement with the report of Banyai et al. (2005) who considered $1 \mathrm{mg} / \mathrm{l} \mathrm{BAP}$ with $0.1 \mathrm{mg} / \mathrm{l} \mathrm{NAA}$ as the best supplemented medium for leaf-explants-derived shoot regeneration. Almaarri and Yu Xie (2010) reported 100 and 66.6\% shoot induction in different genotypes of $A$. annua on MS fortified with TDZ (1 mg/l) and BAP (1 mg/l), respectively. Similar results have also been reported by Sujata and Kumari (2007)=

Those shoot buds that performed well on the prevailing shoot induction medium were transferred into MS supplemented with BAP $(0.25$ - $1.5 \mathrm{mg} / \mathrm{l})$ alone and in combination with $0.5 \mathrm{mg} / \mathrm{l} \mathrm{Kn}$ or $0.1 \mathrm{mg} / \mathrm{l} \mathrm{IBA}$. Cultures were subcultured twice and the effect of hormones on in vitro shoot multiplication of A. annua, anamed cultivar was evaluated.

In this study, the significance of BAP and the interaction of BAP with $\mathrm{Kn}$ and IBA were considered. The ANOVA revealed that the concentration of BAP both alone and in combination with Kn or IBA had a highly significant effect ( $p<$ 0.0001) on shoot multiplication rate. Shoot buds raised from both shoot tip- and nodal explants responded almost similarly on shoot multiplication indicating the non-significant effect of explants at this stage. The proliferation rate had shown a progressive increase from the first sub-culture to the second by an average of $33.3 \%$.

In this study, the best result (number) of shoot proliferation $(10.20 \pm 1.44)$ was obtained on MS containing $0.75 \mathrm{mg} / \mathrm{l} \mathrm{BAP}$ and $0.5 \mathrm{mg} / \mathrm{l} \mathrm{Kn}$ (Table 3). Nevertheless, the microshoots in this medium were less vigorous and bushy as compared to MS fortified with $1 \mathrm{mg} / \mathrm{l} \mathrm{BAP}$ and $0.1 \mathrm{mg} / \mathrm{l} \mathrm{IBA}$ (Fig. 1) resulting in the production of $8.05 \pm 0.66$ shoots (Table 3). In MS containing $0.75 \mathrm{mg} / \mathrm{l} \mathrm{BAP}$ $9.25 \pm 2.88$ shoots with a good morphological appearance were observed. Shoot buds on MS fortified with $0.25 \mathrm{mg} / \mathrm{l} \mathrm{BAP}$ and $0.1 \mathrm{mg} / \mathrm{l} \mathrm{IBA}$ have totally changed into callus while at $0.5 \mathrm{mg} / \mathrm{l}$ and $0.75 \mathrm{mg} / \mathrm{l} \mathrm{BAP}$ together with the same amount of IBA had given better and good shoot proliferation of adventitious origin. The swollen callus like tissue on these media was not friable that may be grouped as organized and semi-organized callus.

An increase in number of shoots per shoot bud culture with increased concentration of BAP from zero up to $1 \mathrm{mg} / \mathrm{l}$ might be due to the effect of BAP in releasing primordia of lateral buds from dormancy or breaking apical dominance by inhibiting the level of endogenous auxins. Cultures on a higher level of above $1 \mathrm{mg} / \mathrm{l} \mathrm{BAP}$ had developed into bushy and ill defined shoot buds and they did not respond when subcultured on the same medium.

The present results are in agreement with those of Banyai et al. (2005) who reported best proliferation rate on $\mathrm{MS}+1 \mathrm{mg} / \mathrm{l} \mathrm{BAP}+0.1 \mathrm{mg} / \mathrm{l} \mathrm{NAA}$. On the other hand, Elhag et al. (1991) reported the development of $14-28$ microshoots 
per shoot bud for different genotypes other than $\mathrm{cv}$. anamed of $A$. annua from shoot tip and lateral buds cultured on both full and half MS fortified with $3 \mathrm{mg} / \mathrm{l}$ BAP. In this study however, cultures on MS containing above $1 \mathrm{mg} / \mathrm{l}$ BAP performed poorly in morphological appearance as well as in number.

Table 3. Effect of BAP, Kn and IBA on in vitro shoot multiplication of A.annua cv. anamed.

\begin{tabular}{|c|c|c|c|}
\hline \multicolumn{3}{|c|}{ Plant growth regulators } & \multirow{2}{*}{$\begin{array}{c}\text { Mean number of } \\
\text { shoots per shoot bud }\end{array}$} \\
\hline $\mathrm{BAP}(\mathrm{mg} / \mathrm{l})$ & $\mathrm{Kn}(\mathrm{mg} / \mathrm{l})$ & IBA (mg/l) & \\
\hline 0.25 & 0.00 & 0.00 & $2.50 n \pm 0.66$ \\
\hline 0.50 & 0.00 & 0.00 & $5.65 \mathrm{i} \pm 0.05$ \\
\hline 0.75 & 0.00 & 0.00 & $9.25 b \pm 2.88$ \\
\hline 1.00 & 0.00 & 0.00 & $8.40 \mathrm{c} \pm 1.44$ \\
\hline 1.25 & 0.00 & 0.00 & $4.451 \pm 1.44$ \\
\hline 1.50 & 0.00 & 0.00 & $3.60 \mathrm{~m} \pm 0.66$ \\
\hline 0.25 & 0.50 & 0.00 & $5.00 \mathrm{k} \pm 0.00$ \\
\hline 0.50 & 0.50 & 0.00 & $7.75 \mathrm{e} \pm 2.88$ \\
\hline 0.75 & 0.50 & 0.00 & $10.20 \mathrm{a} \pm 1.44$ \\
\hline 1.00 & 0.50 & 0.00 & $8.20 \mathrm{~cd} \pm 1.44$ \\
\hline 1.25 & 0.50 & 0.00 & $6.40 \mathrm{~h} \pm 1.44$ \\
\hline 1.50 & 0.50 & 0.00 & $3.55 \mathrm{~m} \pm 0.05$ \\
\hline 0.25 & 0.00 & 0.10 & $0.00 \mathrm{o} \pm 0.00$ \\
\hline 0.50 & 0.00 & 0.10 & $3.45 \mathrm{~m} \pm 0.66$ \\
\hline 0.75 & 0.00 & 0.10 & $6.75 g \pm 0.66$ \\
\hline 1.00 & 0.00 & 0.10 & $8.05 d \pm 0.66$ \\
\hline 1.25 & 0.00 & 0.10 & $7.40 \mathrm{f} \pm 1.44$ \\
\hline 1.50 & 0.00 & 0.10 & $5.30 \mathrm{j} \pm 1.44$ \\
\hline 0.00 & 0.00 & 0.00 & $0.00 n \pm 1.44$ \\
\hline
\end{tabular}

Means with the same letter in a column are not significantly different as determined by Ryan-Einot-Gabriel-Welsch (REGWQ) multiple range test at $\alpha=0.05$.

In this study both IBA and NAA were found to be effective in promoting root induction as well as shoot elongation at half strength MS basal medium. More than $90 \%$ of microcuttings were rooted after three weeks of culture. The highest number of roots $(18.25 \pm 0.95)$, root length $(6.35 \pm 0.10)$ and shoot height $(6.65 \pm 0.05)$ was recorded from half MS containing $0.5 \mathrm{mg} / 1 \mathrm{IBA}$ followed by half MS containing $0.5 \mathrm{mg} / \mathrm{l} \mathrm{NAA}$ resulting $(13.75 \pm 0.50)$ root number, $(5.30 \pm 0.00)$ root length and $(5.70 \pm 0.00)$ shoot height (Table 4$)$. The roots formed in half strength MS were normal - long and thick with many thin branches than on full MS. 

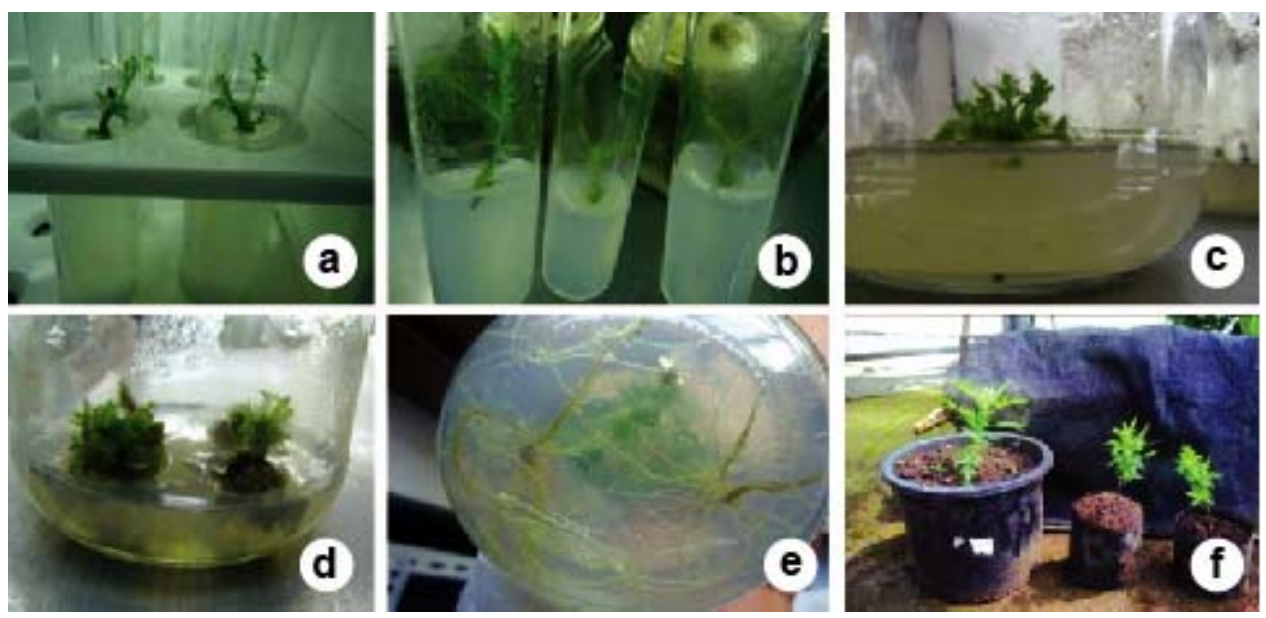

Fig. 1. Axillary shoot buds developed from (a) shoot tip explants on $0.8 \mathrm{mg} / \mathrm{lDZ}$ after three weeks of culture, (b) nodal explants on $0.8 \mathrm{mg} / \mathrm{l} \mathrm{BAP}+0.1 \mathrm{mg} / \mathrm{l} \mathrm{IBA}$ after three weeks of culture, (c) multiple shoots in vitro on $\mathrm{MS}+1 \mathrm{mg} / \mathrm{l} \mathrm{BAP}+0.1 \mathrm{mg} / \mathrm{l} \mathrm{IBA}$ from shoot tip explants, d) multiple shoots in vitro on $\mathrm{MS}+0.75 \mathrm{mg} / \mathrm{l} \mathrm{BAP}+0.5 \mathrm{mg} / \mathrm{Kn} \quad \mathrm{c}$. MS $+1 \mathrm{mg} / \mathrm{l} \mathrm{BAP}$ from nodal explants (e) in vitro rooted shoots in half MS $+0.5 \mathrm{mg} / \mathrm{l} \mathrm{IBA}$ b: Full MS $+0.5 \mathrm{mg} / 1 \mathrm{IBA}$, (f) transplanted and established plantlets in pot/polytene tube (after seven weeks).

Table 4. Effect of MS strength, IBA and NAA on in vitro root initiation and shoot elongation of $A$. annua $\mathrm{cv}$. anamed.

\begin{tabular}{|c|c|c|c|c|c|}
\hline $\begin{array}{c}\text { MS } \\
\text { level }\end{array}$ & $\begin{array}{c}\mathrm{IBA} \\
(\mathrm{mg} / \mathrm{l})\end{array}$ & $\begin{array}{l}\mathrm{NAA} \\
(\mathrm{mg} / \mathrm{l})\end{array}$ & $\begin{array}{c}\text { Number of } \\
\text { roots }\end{array}$ & $\begin{array}{c}\text { Root length }(\mathrm{cm}) \\
\text { mean } \pm \text { S. D. }\end{array}$ & $\begin{array}{c}\text { Shoot height } \\
(\mathrm{cm}) \text { mean } \pm \text { S.D. }\end{array}$ \\
\hline $1 / 2$ & 0 & 0 & $7.50 \mathrm{e} \pm 5.94$ & $2.74 \mathrm{ef} \pm 2.26$ & $4.22 \mathrm{~cd} \pm 1.40$ \\
\hline $1 / 2$ & 0.5 & 0 & $18.25 a \pm 0.95$ & $6.35 a \pm 0.10$ & $6.65 a \pm 0.05$ \\
\hline $1 / 2$ & 1 & 0 & $8.75 \mathrm{~d} \pm 0.50$ & $4.17 c \pm 0.09$ & $4.75 c \pm 0.10$ \\
\hline MS & 0 & 0 & $4.25 \mathrm{~h} \pm 3.25$ & $1.60 \mathrm{~h} \pm 1.19$ & $2.68 \mathrm{f} \pm 0.71$ \\
\hline MS & 0.5 & 0 & $11.75 c \pm 0.50$ & $3.67 d \pm 0.05$ & $4.22 \mathrm{~cd} \pm 0.05$ \\
\hline MS & 1 & 0 & $6.25 f \pm 0.50$ & $2.45 f \pm 0.10$ & $2.57 f \pm 0.05$ \\
\hline $1 / 2$ & 0 & 0.5 & $13.75 b \pm 0.50$ & $5.30 \mathrm{~b} \pm 0.00$ & $5.70 \mathrm{~b} \pm 0.00$ \\
\hline $1 / 2$ & 0 & 1 & $8.75 \mathrm{~d} \pm 0.50$ & $2.92 \mathrm{e} \pm 0.05$ & $4.52 c \pm 0.12$ \\
\hline MS & 0 & 0.5 & $7.25 \mathrm{e} \pm 0.50$ & $2.62 \mathrm{ef} \pm 0.05$ & $3.47 \mathrm{e} \pm 0.15$ \\
\hline MS & 0 & 1 & $5.50 \mathrm{~g} \pm 0.57$ & $2.17 \mathrm{~g} \pm 0.05$ & $2.75 f \pm 0.10$ \\
\hline
\end{tabular}

Means with the same letter in a column are not significantly different as determined by REGWQ at $\alpha=0.05$.

These results are in agreement with those reported by Nair et al. (1986) and Elhag et al. (1991) concerning the better performance of half strength MS for in vitro rooting of $A$. annua in terms of rooting i.e., $>75$ and $100 \%$ rooting in three weeks with the addition of $0.5 \mathrm{mg} / \mathrm{l}$ of either IBA, NAA or IAA and $0.3 \mathrm{mg} / \mathrm{l}$ NAA, respectively. Almaarri and Yu Xie (2010) also noted the same results in 
half MS fortified with $1 \mathrm{mg} / \mathrm{l}$ IBA. Said medium yielded optimum results in that it gave $80 \%$ rooting after 20 days. The present results however-showed reduction in rooting affected by increased concentration of both IBA and NAA from 0.5 to 1 $\mathrm{mg} / \mathrm{l}$. This may be due to the high concentration of auxin in the range that normally stimulates elongation of shoots $\left(10^{-5}\right.$ to $\left.10^{-6} \mathrm{M}\right)$, with concomitant significant inhibition of root growth. The inhibition of root growth and development might partly be due to the ethylene production which is triggered by high auxin concentration (Hopkins and Huner 2004, Hartman et al. (2009). Jamaleddine et al. (2011) reported MS $+0.1 \mathrm{mg} / \mathrm{l} \mathrm{Kn}+0.01 \mathrm{mg} / \mathrm{l} \mathrm{NAA}$ as optimum for shoot elongation. In the present study however best shoot heights were observed from cultures on half strength MS than full MS fortified with $0.5 \mathrm{mg} / \mathrm{l}$ IBA or NAA (Table 4)

In the present study, employing the acclimation procedure indicated in the methodology, the plantlets showed $80 \%$ survival efficiency. There were no observable variations with respect to morphological and growth characteristics between ex vitro grown parent plants and in vitro raised potted plants. The transplanted plants established well in pots (Fig. 1)

\section{Acknowledgements}

Authors would like to thank the authority of Jimma Univesity for financial support, Jimma Agriculture Research Center for supplying laboratory and chemicals and all staff members for their cooperation thoughout the experimental period.

\section{References}

Almaarri K and Yu Xie (2010). In vitro direct organogenesis and micropropagation of Artemisia annua. J. Biotechnologie Vegetale 26: 327-337.

Aslam N, Zia and Chaudhary MF (2006). Callogenesis and direct organogenesis of Artemisia scoparia. Pakistan J. Biol. Sci. 9: 1783-1783.

Banyai W, Nakamura I, Mii M and Supaibulwatana K (2005). High regeneration frequency of transgenic plants in Artemisia annua L. by Agrobacterium tumefaciensmediated gene transformation. Proceedings of the 10th international congress of SABRAO. 22-24 August 2005. The University of Tsukuba, Japan 2005.

EABL (2005). Growers' production manual for Artemisia annua. East African Botanicals Ltd. 2005.

Elhag H, EL-Feraly F, Mossa JS and Hafez M (1991) In vitro propagation of Artemisia annua L. J. King Saud Univ. 3: 251-259.

Ferreira JFS and Janick J (1995) Floral morphology of Artemisia annua with special reference to trichomes. Int. J. Plant Sci. 156: 807-815. 
Ferreira JFS, Laughlin JC, Delabays N and Magalhaes PM (2005). Cultivation and genetics of Artemisia annua L. for increased production of the anti-malarial artemisinin. Plant genetic resources: characterization and Utilization 3: 206-229.

George EF, Hall MA and De Clerk GJ (2008) Plant propagation by tissue culture. Third Edition: Springer. Dordrecht.

Govindaraj S, Kumary BD, Gioni PL and Flamini G (2008) Mass propagation and essential oil analysis of Artemisia vulgaris, J. Bioscience and Bioengineering 105: 176183.

Hartmann HD, Kester DZ, Davies JR and Geneve RL (2009) Plant propagation; principles and practices, seventh edition. PHl Learning Private Limited. New Delhi.

Hopkins GW and Huner NP (2004) Introduction to plant physiology. Third Edition. John Wiley and Sons, Inc. USA.

Hu CY and Wang PJ (1983) Meristem, shoot tip and bud culture, In: Envans, D.A.; Sharp, W.R.; Ammiratto. P.V and Yamada, Y. (eds.). Handbook of Plant Cell Culture, Vol. 1. New York; Macmillan.

Jamaleddine ZO, Lyam P, Fajimi O, Giwa A, Aina A, Lawyer EF, Okere AU and Odofin WT (2011) In vitro growth response of Artemisia annua seeds to different concentrations of plant growth regulators. African J. Biotechnol. 10: 17841-17844. .

Nair MR, Acton N, Klayman DL, Kendrick K, Basile DV and Mante S (1986) Production of artemisinin in tissue cultures of Artemisia annua. J. Nat. Prod., 49: 504-507.

Nibret E and Wink M (2010) Volatile components of four Ethiopian Artemisia species extracts and their in vitro anti-trypanosomal and cytotoxic activity. Phytomedicine; 17: 369-374.

Sujata G and Kumari BD (2007) Effect of phytohormones on micropropagation of Artemisia vulgaris L. Acta Physiol. Plant 29: 189-195.

Tiruneh G, Kebede $\mathbf{Y}$ and Yigzaw T (2010). Use of the plant Artemisia annua as a natural anti-malarial herb in Arbaminch town. Ethiop. J. Health Biomed. Sci. 2: 75-81.

WHO (2003) Guidelines on good agricultural and collection practices [GACP] for medicinal plants. World Health Organization, Geneva, 2003

WAC (World Agroforestry Centre) (2007) African malaria day special report: artemisia, a homegrown cure for malaria. www.World Agroforestry.org. 